\title{
New Social Risk Groups, Industrial Relations Regimes and Union Membership
}

\section{Shin, Young Kyu}

2018-07-01

Shin , Y K \& Ylä-Anttila , M T 2018 , ' New Social Risk Groups, Industrial Relations Regimes and Union Membership ' , Journal of European Social Policy , vol. 28 , no. 3 , pp. 242-254 . https://doi.org/10.1177/0

http://hdl.handle.net/10138/237146

https://doi.org/10.1177/0958928717735054

acceptedVersion

Downloaded from Helda, University of Helsinki institutional repository.

This is an electronic reprint of the original article.

This reprint may differ from the original in pagination and typographic detail.

Please cite the original version. 


\title{
New social risk groups, industrial relations regimes and union membership
}

\author{
Young-Kyu Shin and Tuomas Ylä-Anttila
}

\begin{abstract}
The literature on new social risk groups (NSRs), such as single parents and temporary workers, has argued that they are less likely to join trade unions than other employees. It has been suggested that this is due to the unions' incapacity or unwillingness to promote policies that mediate new social risks. We argue that there are differences in unionization between different NSR groups, and that country-level institutional structures, operationalized here as industrial relations regimes, have effects on how likely NSR groups are to unionise. Our multilevel logistic models using ESS survey data produce three main results: (1) Family policy related NSR groups (single parents, female employees with children and female caregivers) are more - not less - unionised than the average worker, (2) precarious workers (low-skilled service employees, temporary employees and part-timers) are, indeed, less unionised than average but (3) this result concerns mostly the liberal and transitional industrial relations regimes.
\end{abstract}

\section{Keywords}

New social risks, trade unions, union membership, industrial relations regimes, European Social Survey 


\section{Introduction}

Since the late 20th century, much research has paid attention to new types of social issues, such as work-life imbalance, long-term care, labour market segmentation, and precarious workers (see Bonoli, 2006; Esping-Andersen, 1999; Häusermann and Schwander, 2012; Kalleberg, 2009; Morel et al., 2012; Taylor-Gooby. 2004). Multiple scholars have labelled these social phenomena "new social risks" (NSRs), pointing out that old social risks (OSRs) refer to those that people tried to overcome during industrialisation, such as unemployment, illness and disability, while NSRs refer to those that individuals face in their lives because of the socio-economic transformations during the transition to a post-industrial society (Taylor-Gooby, 2004; Bonoli, 2006; Bonoli, 2007). In regard to the appellation 'new', it should be pointed out that the risk factors subsumed in the concept are not completely new phenomena and that the 'new' indicates the increased volume of these risks and the consequent creation of welfare needs; OSRs still coexist (Harsløf and Ulmestig, 2013).

Studies show that the growth of NSRs are closely affiliated with structural transformations of labour markets in the post-industrial age such as the feminisation of the workforce, the growth of service sector employment, and the diversification of employment patterns, and that existing welfare states are required to reform their social policy in order to respond to NSRs properly. At the same time trade unions, which were major advocates of welfare expansion in the development of the post-war welfare states, 
have experienced the decline in their ability to institutionally influence government decision making in most European countries (Ebbinghaus, 2006; Allern et al., 2007). If the unions are indeed losing ground, is this because the particular employee groups facing new social risks are less likely to become union members? Many scholars have argued that this is the case (Bonoli 2005; Ebbinghaus 2006; Häuserman 2012).

In this study we scrutinise this claim by looking into differences in the unionisation of different groups of people facing new social risks, and examining whether the macro-institutional context of a country, here operationalized as the industrial relations regime, has an effect on the unionization of NSR groups. Following Bonoli (2006), Häusermann and Schwander (2012) and Kalleberg (2009), we differentiate between six groups of people facing new social risks: 1) single-parent employees, 2) female employees with children, 3) female employees who care for vulnerable family members, 4) low-skilled employees working in the service industry, 5) temporary employees, and 6) part-time employees ${ }^{1}$. These six groups can be classified into two categories. The first three groups can be called "family policy related NSR groups" in that the risks they are facing can be dealt with mainly by expanding family policy in welfare states. The latter three can be labelled "precarious worker

\footnotetext{
${ }^{1}$ Bonoli (2006) also includes people with insufficient social security coverage in his definition of NSR groups. In this paper we exclude this group due to limitations of our dataset. Like most other studies on union membership we also exclude unemployed people from the analysis. This is because in most countries they cannot join trade unions.
} 
groups" because the groups are highly likely to work in more unstable and less protected working conditions than those in full-time and fully insured employment.

To examine the influence of the macro-institutional context on the unionisation of NSR groups, we classify the 23 European countries included in this study into five industrial relations regimes, following Visser (European Commission, 2009): 1) organised corporatism, 2) social partnership, 3) polarised/state-centred, 4) liberal, and 5) transitional.

Using data from the European Social Survey Round $5(N=52,458)$ we estimate multilevel logistic regression models to assess the likelihood of union membership among different NSR groups. To investigate the effect of IR regimes we estimate models for each regime separately.

Our results show that (1) family policy related NSR groups (single parents, female employees with children and female caregivers) are more - not less - unionised than the average worker, (2) precarious workers (low-skilled service employees, temporary employees and part-timers) are, indeed, less unionized than average but (3) this result concerns mostly the liberal and transitional industrial relations regimes. Interestingly, we also find that union efforts to organise one particular group of precarious workers - low-skilled service sector workers - in the liberal regime have paid off: they are more likely to be unionised than the average worker. 


\section{Hypotheses: what affects the unionization of NSR groups}

Prior research has shown that the socio-demographic groups that have a higher chance of coming face-to-face with new social risks - such as female, young, low-skilled, parttime and temporary workers - are less unionised than the average worker (Ebbinghaus 2006). Several scholars have argued that the main explanation for the low rate of unionisation is that trade unions seem not to be willing or able to explicitly defend the interests of NSR groups (Bonoli, 2005; Ebbinghaus, 2006; Häuserman; 2012).

We see two main limitations in this literature. First, it tends to lump together all new social risk groups from single mothers to precarious workers, arguing that they are, as a whole, less likely to unionise. But what if only some of these groups are less likely to join unions, while others are just as likely or even more likely than the average employee? Second, the literature tends not to differentiate between micro (individual, workplace-level, union-level) and macro-institutional (country-level) explanations. But what if the NSR groups are less unionised only in countries characterized by a certain type of industrial relations regimes? Or what if there is an association between the type of NSR group and unionisation that varies between different types of country contexts? In what follows, we first develop hypotheses concerning the differences in unionisation between individuals belonging to different NSR groups, and second, hypotheses concerning the effects of country-level institutional structures on NSR unionisation. 


\section{The individual level: differences between NSR groups}

As noted above, most literature on NSRs and unions argues that the NSR groups across the board are less unionised than other workers, and that this is due to the unions not doing much for them (Bonoli, 2005; Ebbinghaus, 2006; Häuserman, 2012). But looking at the possible differences between the different NSR groups leads us to hypothesize that this association may only hold for some NSR groups and not others. For part-time and temporary workers, Gumbrell-McCormick's (2011) qualitative study in ten European countries including France, Germany, the Netherlands, Sweden and the UK, shows that many unions do tend to exclude them and focus their efforts on full-time workers. Under such circumstances, it is obviously less likely for part-timers and temporary workers to join unions. Thus, concerning the three NSR groups we have called precarious workers, our hypothesis is:

H1: Precarious workers (part-time, temporary and low-skilled service sector workers) are less frequently unionized than other employees.

However, for the family policy related NSR groups - single-parent employees, working mothers and female employees who care for vulnerable family members - the situation may be different. The literature seems to suggest that the trade union's difficulties or unwillingness to deal with NSR groups may not extend to family policy related ones. Eurofound's (2010) report on trade unions' strategies to recruit new members in the 27 
EU member countries and Norway found that unions in most countries have, during the past few decades, worked very hard to mobilise female workers, including those belonging to NSR groups. What is more, there is a body of research showing that trade unions have had positive effects on extending family policies in many European countries (Earles 2011; Yerkes and Tijdens 2010; Gregory and Milner 2009; Budd and Mumford 2004). To the extent that workers are aware of these positive effects of unions and the efforts of the unions to mobilise the family policy related NSR groups have been successful, our hypothesis concerning these groups is:

H2: Family policy related NSR groups (single-parent employees, working mothers and female employees who care for vulnerable family members) are unionised as frequently as other workers.

\section{The macro-institutional level: differences between industrial relations regimes}

The comparative literature on NSR groups in different countries has focussed mostly on the ability of different welfare state regimes (Esping-Andersen, 1999) to respond to the rise of new social risks. Bonoli (2007), for example, finds that the Nordic countries are leaders in NSR policies. The argument is that countries that started early to experience post-industrialisation, such as Nordic countries and the United Kingdom, had opportunities to invest continuously in ameliorating NSRs, whereas countries that 
entered post-industrial societies later, such as the Continental and Southern European countries, have difficulty raising the resources to respond to NSRs, particularly in the age of austerity.

In examining the associations between NSR groups and union membership, however, the perspective of welfare regimes can be problematic. Although it is clear that the institutional features of welfare states affect people facing NSRs, it may not be welfare systems as such that have direct causal effects on their decision to join unions. Thus, to differentiate between the macro-institutional structures of different countries that have effects on union membership, we argue the concept of industrial relations regimes (henceforth IR regimes) is more useful than that of welfare state regimes. Visser (European Commission, 2009) distinguishes between five regimes in Europe: 1) organised corporatism, 2) social partnership, 3) polarised/state-centred, 4) liberal, and 5) transitional. Table 1 presents the classification of the 23 European countries analysed in this paper to these categories. ${ }^{2}$

\footnotetext{
${ }^{2}$ The typology expands on Ebbinghaus and Visser (1997) and Crouch (1993). We find it more useful for the present analysis than Gallie's (2007) similar typology because the latter does not include East European countries and fails to assign Ireland into any category.
} 
Table 1 Countries classified by industrial relations regimes

\begin{tabular}{c|c}
\hline Regime & Countries \\
\hline Organised corporatism & Denmark, Finland, Norway, Sweden \\
\hline Social partnership & Belgium, Germany, The Netherlands, \\
Slovenia, Switzerland
\end{tabular}

Note: This table includes only the countries which took part in the ESS round 5. In Iceland, Italy and Luxembourg, the survey was not conducted in 2010.

We hypothesize that rates of unionisation of NSR groups are higher in those IR regimes where collective bargaining coverage is the widest, and where unions have more influence on governmental policy making, as opposed to just workplace level bargaining. Data from the European Trade Union Institute (2014) shows that in liberal and transitional regimes collective bargaining covers only 40 and 30 per cent of employees, respectively. In the organised corporatism, social partnership, and polarised/state-centred IR regimes, in contrast, the average collective bargaining 
coverage is over 75 per cent. ${ }^{3}$ In the countries where coverage is high, unions tend to have significant influence on governmental decision making on labour and social policy (Weiler, 2004). This should provide NSR workers with more incentives to join unions in the IR regimes with high bargaining coverage. Keeping in line with our first two hypotheses, we expect these effects to apply in particular to precarious workers. Thus, our third and fourth hypotheses are:

H3: In the liberal and transitional IR regimes, precarious workers are less likely to be union members than other employees.

H4: In the organised corporatism, social partnership and polarised/state-centred regimes, precarious workers are as likely to be union members as other workers.

Figure 1 summarizes our explanatory model, focusing on the effects of the particular NSR group an individual belongs to on the one hand, and the institutional structure of NSR regime under which the individual lives in on the other, on whether or not she or he decides to join a trade union. That is to say, we assume that whether individuals experience NSRs and in which IR regime they are employed affect their membership status simultaneously.

\footnotetext{
${ }^{3}$ The percentages are calculated including only the countries analysed in this study on the basis of the data from the European Trade Union Institute (2014).
} 
Figure 1 Explanatory model

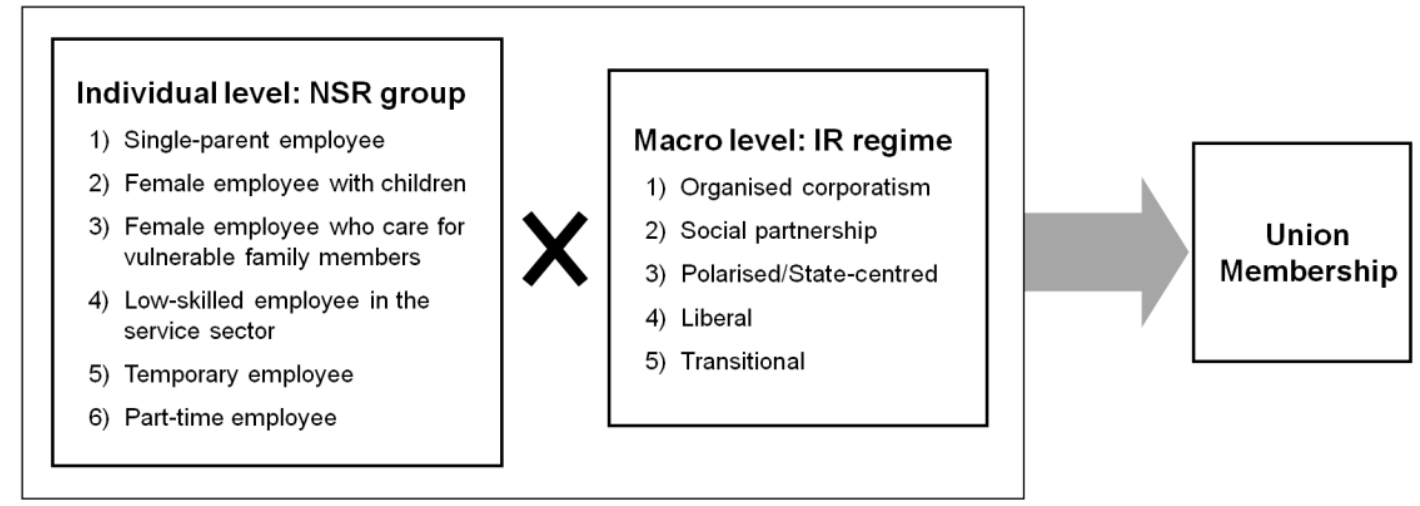

\section{Data and methods}

The main source of data for this research is microdata obtained from the European Social Survey Round 5 (edition 3.2), conducted in 2010. This data allows to distinguish between people belonging to NSR groups by providing information on the birth years of the family members of all respondents; the respondents' relationship to them; as well as on the economic activity status of their husband, wife, or partner if they are married or cohabitate. We analyse the observations from those 23 ESS countries that can be classified according to Visser's (European Commission, 2009) typology of industrial relations regimes. Three countries included in the typology, Italy, Iceland and Luxembourg, did not participate in ESS round 5 and are, thus, omitted from our analysis. Lastly, these data are combined with data that includes the variable of the Ghent system. 
Many studies on the determinants of union membership that use cross-national survey data disregard the hierarchical structure of the data. When data have hierarchical levels such as student-classroom-school, or, in our case individual-country, it can be expected that individual units selected from the same group in a level are likely to have more similar characteristics than those selected from different groups. In addition, they are likely to be interdependent within each group. This expectation violates the basic assumption of generalised linear models that randomly selected individuals or units are independent of each other. Therefore, Hox and Roberts (2011) suggest using multilevel analysis whenever research questions extend over different levels and data consist of variables at two or more hierarchical levels. It has, indeed, become the standard practice to use multilevel modeling to analyse datasets including multiple countries extracted from ESS data (Kemppainen, 2012). Moreover, Brady (2007) emphasises the importance of multilevel modelling in the specific case of analysing the determinants of union membership using cross-national data. Therefore, we estimate multilevel binary logistic models by industrial relations regimes with the dichotomous response variable (current union member $=1$ and 0 otherwise) to explore the degree of unionisation of different NSR groups.

We only analyse the cases of respondents who are currently both employed and aged between 15 and 64, because retirees, children, and in most IR regimes, the unemployed cannot join trade unions. When estimating statistical models, we apply 
population and post-stratification weight values to consider the characteristics of the populations in the countries included in the data. The first weight values corresponding to each country are newly calculated for this research, while the second weight values come from the ESS data. ${ }^{4}$

The six NSR groups are operationally defined as follows: First, the single-parent employee is an employee who does not reside with a husband, wife, or partner and who has one or more son or daughter, which could include a step-, adopted, or foster child, who is younger than 18 years old and living at home. Second, the female employee with children is a female employee who has children meeting the same criteria as mentioned above for the single-parent employee, but who lives with a husband or partner. In order to remove the overlap with the first group, this definition includes only women who cohabit with a spouse or partner. Third, the female employee who cares for vulnerable family members is a female employee who resides with a permanently sick or disabled husband or partner, with a retired husband or partner over 65 years old, or with parents or parents-in-law over 65 years old. Fourth, the low-skilled employee in the service sector is an employee who works in the service industry and whose highest level of

${ }^{4}$ The formula for calculation of population weights, derived by applying the formula to calculate the population size weight in the ESS (European Social Survey, 2014), is as follows: Population weight $=($ Employed population aged 15 to 64 in 2010 $) /\{($ Sample size $) \times 10000\}$ The sources come from "Eurostat" (European Commission, 2014). 
education is ES-ISCED I or II. ${ }^{5}$ Next, the temporary employee is an employee who has a fix-term employment contract. Lastly, the part-time employee is an employee whose working time is less than 35 hours per week.

We control for the following variables: gender (male=0, female=1), age (in years), age squared, education (five dummy variables), citizenship (citizen=0, immigrant $=1)^{6}$, ethnic group (major $=0$, minor $\left.=1\right)^{7}$, industry (five dummy variables, which include manufacturing, construction, services, public administration and defence and others), workplace type (private $=0$, public $=1$ ), union representativeness at the workplace (ranging from no unions or union members $=0$, little or no influence $=1$, to a great deal of influence $=4$ ), and establishment size (five dummy variables). We also include one country-level control variable, the Ghent system (Ghent country=1 if the country has the Ghent system and 0 otherwise). Because the Ghent countries include Belgium, Denmark, Finland, and Sweden, this variable is only included in the organised corporatism and social partnership models.

${ }^{5}$ The service industry consists of economic activities corresponding to the category number from 45 to 97 except 84 in the Statistical classification of economic activities in the European Community (NACE) rev. 2. In addition, this research defines low-skilled workers as those who finished education at a level lower than ES-ISCED IIIb on the basis of Schneider's (2009) research to show that education equivalent to ES-ISCED I and II does not grant a vocational qualification.

${ }^{6}$ If a respondent's nationality is coincident with the country where he/she have a job, the respondents is a citizen. Otherwise, he/she is an immigrant.

${ }^{7}$ If a respondent's race is not included in the major ethnic group of the country where he/she have a job, the respondent is an ethnic minority regardless of nationality. 
Recent research about the determinants of union membership (Blanchflower, 2007; Ebbinghaus et al., 2011; Scheuer, 2011; Schnabel and Wagner, 2007), leads us to expect the following effects for the control variables. The effect of gender on unionisation has been shown to depend on the IR regime; women tend to be more unionised than men in the organised corporatism but less in other regimes. Concerning age and education, in older and more highly educated workers tend to be more likely to join unions across the all IR regimes. Immigrant workers and ethnic minorities are usually less active in joining unions than others. In terms of industries and sectors, employees working in manufacturing tend to be more active in unionising than those in other industries, and public sector workers are more likely to join unions than those in the private sector. In addition, we expect that the stronger the unions' influence at the workplace, the more active employees are in having union membership. Large establishment size also tends to have a positive impact on union membership. Lastly, the Ghent system has been shown to have a significant positive effect on unionisation (Ebbinghaus et al., 2011; Rothstein, 1990; Western, 1994). In this system of unemployment insurance management, employees have high incentives to join unions, because the unions administer unemployment insurance funds subsidised by the state, and unemployment insurance is thus dependent on union membership ${ }^{8}$.

\footnotetext{
${ }^{8}$ The Ghent system countries are Denmark, Finland, Sweden and Belgium. Although Belgium no longer has the voluntary, state-subsidized, union-run unemployment funds, the country can
} 


\section{Results}

\section{Descriptive analyses}

To begin with, in order to observe how much NSRs could impact the labour market and trade unions, it is necessary to explore how many employees face NSRs. Table 2 shows the estimates of NSR populations among employed people in each regime, the calculations for which were performed by applying weight values. The results reveal that in every regime, about half of employees experience at least one type of NSR. There is no big difference in the shares of single-parent employees, working mothers, and female employees who care for vulnerable family members between regimes. When it comes to precarious workers, however, the differences across regimes are notable. The figures for low-skilled service workers are below $10 \%$ in the organised corporatism, social partnership and transitional regimes, while those in the polarised/state-centred and liberal regimes are $17.5 \%$ and $20.8 \%$, respectively. Regarding temporary employees, the rate in the organised corporatism is the lowest among all regimes accounting for 9.4\%, whereas the transitional regime has the highest percentage, $22.3 \%$. Lastly, while the social partnership and liberal regimes indicate over $30 \%$ of part-time workers, the shares of part-time workers in the other regimes do not reach $20 \%$.

be considered as a Ghent country because the current Belgian unemployment insurance system, where trade unions continue to play a pivotal role, still encourages unionisation as if it were a Ghent system (Vandaele, 2006). 
Table 3 depicts the estimated employment rates of all samples, single parents, women with children, women who care for vulnerable family members and low-skilled people. The employment rates of single parents are similar to the averages in the all regimes except for the organised corporatism, where the figure is even higher than the average. Working mothers' employment rates are far higher than the averages in every regime, whereas female caregivers and low-skilled people shows much lower employment rates than the averages in all IR regimes. Consequently, the findings show that female caregivers and low-skilled people have more serious difficulties in employment.

Table 2 Shares of employed new social risk groups by industrial relations regimes (\%)

\begin{tabular}{|c|c|c|c|c|c|}
\hline NSR group & $\begin{array}{l}\text { Organised } \\
\text { corporatism }\end{array}$ & $\begin{array}{c}\text { Social } \\
\text { partnership }\end{array}$ & $\begin{array}{c}\text { Polarised/ } \\
\text { state-centred }\end{array}$ & Liberal & Transitional \\
\hline Single-parent employees & 6.2 & 5.5 & 6.1 & 8.2 & 7.2 \\
\hline $\begin{array}{l}\text { Female employees } \\
\text { with children }\end{array}$ & 20.1 & 18.3 & 22.0 & 19.4 & 22.4 \\
\hline $\begin{array}{l}\text { Female employees who care } \\
\text { for vulnerable family members }\end{array}$ & 1.8 & 2.0 & 3.0 & 1.4 & 4.8 \\
\hline $\begin{array}{l}\text { Low-skilled } \\
\text { service employees }\end{array}$ & 9.5 & 9.0 & 17.5 & 20.8 & 8.2 \\
\hline Temporary employees & 9.4 & 15.3 & 18.0 & 12.7 & 22.3 \\
\hline Part-time employees & 18.9 & 33.0 & 18.0 & 30.5 & 10.0 \\
\hline All NSR groups & 47.3 & 51.1 & 57.4 & 57.1 & 54.7 \\
\hline
\end{tabular}

Source: Authors' calculations based on the ESS round 5 data

Note: The proportions of all NSR groups are different from the sum of the proportions of each group because some respondents are included in multiple NSR groups. 
Table 3 Estimated employment rates of people facing new social risks by industrial relations regimes $(\%)$

\begin{tabular}{|c|c|c|c|c|c|}
\hline & $\begin{array}{l}\text { Organised } \\
\text { corporatism }\end{array}$ & $\begin{array}{c}\text { Social } \\
\text { partnership }\end{array}$ & $\begin{array}{c}\text { Polarised/ } \\
\text { State-centred }\end{array}$ & Liberal & Transitional \\
\hline Single parents & 69.3 & 49.2 & 43.3 & 46.6 & 39.5 \\
\hline Women with children & 72.2 & 59.4 & 51.5 & 55.9 & 50.1 \\
\hline $\begin{array}{l}\text { Women who care for } \\
\text { vulnerable family members }\end{array}$ & 15.7 & 12.7 & 13.4 & 11.0 & 26.1 \\
\hline Low-skilled people & 27.9 & 30.4 & 25.4 & 32.2 & 23.6 \\
\hline Average of all samples & 51.2 & 48.7 & 41.2 & 45.0 & 42.3 \\
\hline
\end{tabular}

Source: Authors' calculations based on the ESS round 5 data

\section{Multilevel logistic estimates for union membership}

Table 4 displays the estimates of multilevel binary logistic models for union membership by the five regimes. Our first hypothesis stated that precarious workers (part-time, temporary and low-skilled service sector workers) are less frequently unionised than other employees. This hypothesis is supported only partially. It holds only for some groups of precarious workers and mainly in the liberal and transitional IR regime. The groups that are less unionised than average are temporary employees in the transitional, liberal and social partnership regimes, part-time employees in liberal and polarised/state-centred regimes and low-skilled service employees in the transnational regime. One group of precarious workers in one regime counters the hypothesis: Low- 
skilled service employees in the liberal regime are more unionised than the average worker, rather than less.

Our second hypothesis was that the family policy related NSR groups (working mothers, single-parent employees and female employees who care for vulnerable family members) are unionised as frequently as other workers. This hypothesis is supported. No family policy related NSR group under any IR regime is less unionised than the average worker. In fact, several of these groups in several regimes are significantly more unionised than average. Female employees with children are more unionised than average in the organised corporatism, social partnership and liberal regimes. In the liberal regime, single parent employees and female caregivers are also more unionised than average.

Our third hypothesis focussed on the difference between the IR regimes, stating that in the liberal and transitional IR regimes, precarious workers are less likely to be union members than other employees. This hypothesis, again, finds partial support. Temporary employees are less unionised in both regimes, as are part-time employees in the liberal regime and low-skilled service employees in the transitional regime. However, low-skilled service employees are more likely to be unionised in the liberal regime than the average worker.

Our fourth hypothesis stated that in the organised corporatism, social partnership and polarised/state-centred regimes, precarious workers are as likely to be union 
members as other workers. This hypothesis is mostly supported. All three groups in all three regimes do not show significant differences from the average worker, except for temporary employees in the social partnership regime and part-time employees in the polarised/state-centred regime.

The effects of the control variables are largely as expected. The Ghent system has the largest effect. In countries of the organised corporatism, having a Ghent system results in more than a threefold increase in unionisation, and in social partnership countries almost eightfold. Public sector workers are more unionised than others, the rate varying from almost double in the social partnership to more than fourfold in the liberal IR regime. Unions' influence at the workplace almost doubles the rate of unionisation across the IR regimes. Older employees are more unionised than the young ones everywhere except for the social partnership regime. Women are less likely to be unionised than men in the social partnership and liberal regimes, but are more unionised than men in the organised corporatism. This is coherent with the results of Schnabel and Wagner (2007). Employees in large establishments are more likely to be unionised than those in small establishments in all except of the transitional IR regime. Manufacturing workers are significantly more unionised than those in the other industries only in the social partnership IR regime. Education results in fairly few statistically significant differences, somewhat contrary to our expectations. Perhaps the main divergence from our expectations concerns ethnic minorities. While immigrants (defined as non-citizens 
of the country they work in) are significantly less unionised in most IR regimes as expected, this applies to ethnic minorities only in the state-centred regime. In the organised corporatism and especially the liberal IR regime, minorities are more, unionised than others, not less as the literature led us to expect. 
Table 4 Multilevel binary logistic estimates for union membership by industrial relations regimes

\begin{tabular}{|c|c|c|c|c|c|}
\hline Variable & $\begin{array}{l}\text { Organised } \\
\text { corporatism }\end{array}$ & $\begin{array}{l}\text { Social } \\
\text { partnership }\end{array}$ & $\begin{array}{l}\text { Polarised/ } \\
\text { State-centred }\end{array}$ & Liberal & Transitional \\
\hline \multicolumn{6}{|l|}{ New social risk groups } \\
\hline 1. Single-parent employee & $0.98 \quad(0.316)$ & $0.95 \quad(0.226)$ & $0.66 \quad(0.455)$ & $1.15^{* *}(0.031)$ & $1.37 \quad(0.171)$ \\
\hline 2. Female employee with children & $1.28 * *(0.049)$ & $1.47 *(0.185)$ & $0.86 \quad(0.168)$ & $2.13 * *(0.070)$ & $1.17 \quad(0.090)$ \\
\hline $\begin{array}{l}\text { 3. Female employee who cares for } \\
\text { vulnerable family members }\end{array}$ & $1.78 \quad(0.314)$ & $1.15 \quad(0.078)$ & $1.31 \quad(0.973)$ & $2.21 * *(0.107)$ & $1.25 \quad(0.306)$ \\
\hline 4. Low-skilled service employee & $1.08 \quad(0.673)$ & $1.01 \quad(0.066)$ & $0.80 \quad(0.142)$ & $1.20 *(0.091)$ & $0.40 * *(0.183)$ \\
\hline 5. Temporary employee & $0.66 \quad(0.263)$ & $0.76^{*}(0.131)$ & $0.53 \quad(0.401)$ & $0.45^{* *}(0.097)$ & $0.39 * *(0.172)$ \\
\hline 6. Part-time employee & $0.81 \quad(0.151)$ & $0.76 \quad(0.213)$ & $0.67 * *(0.083)$ & $0.76^{* *}(0.020)$ & $1.16 \quad(0.090)$ \\
\hline Intercept & $0.00 * *(0.873)$ & $0.06^{* *}(0.207)$ & $0.00 * *(1.376)$ & $0.00 * *(0.237)$ & $0.00 * *(0.744)$ \\
\hline \multicolumn{6}{|l|}{ Individual-level controls } \\
\hline Female & $1.41 * *(0.077)$ & $0.81 * *(0.060)$ & $0.92 \quad(0.082)$ & $0.83 * *(0.003)$ & $0.86 \quad(0.087)$ \\
\hline Age & $1.22 * *(0.039)$ & $1.00 \quad(0.018)$ & $1.26^{* *}(0.071)$ & $1.03 * *(0.006)$ & $1.16^{* *}(0.032)$ \\
\hline Age squared & $1.00 * *(0.000)$ & $1.00 \quad(0.000)$ & $1.00 * *(0.001)$ & $1.00 \quad(0.000)$ & $1.00 * *(0.000)$ \\
\hline \multicolumn{6}{|l|}{ Education } \\
\hline - ES-ISCED I or II & $0.79 \quad(0.652)$ & $1.49 \quad(0.208)$ & $0.74 \quad(0.168)$ & $1.32 *(0.073)$ & $1.15 \quad(0.221)$ \\
\hline - ES-ISCED IIIb & $1.45 \quad(0.275)$ & $1.66^{*}(0.257)$ & $0.53 * *(0.122)$ & $0.94 \quad(0.077)$ & $0.90 \quad(0.095)$ \\
\hline - ES-ISCED IIIa & Ref. & Ref. & Ref. & Ref. & Ref. \\
\hline - ES-ISCED IV & $0.81 * *(0.044)$ & $1.31 \quad(0.230)$ & $0.66 \quad(0.482)$ & $1.41 * *(0.044)$ & $0.93 \quad(0.336)$ \\
\hline - ES-ISCED V1 or V2 & $0.86 \quad(0.165)$ & $1.26 \quad(0.330)$ & $0.68 \quad(0.361)$ & $1.38 * *(0.077)$ & $0.86 \quad(0.136)$ \\
\hline Immigrant & $0.49 *(0.287)$ & $0.61 \quad(0.311)$ & $0.22 * *(0.371)$ & $0.48^{* *}(0.177)$ & $1.99 \quad(0.627)$ \\
\hline Minority ethnic group & $1.31 * *(0.072)$ & $0.75 \quad(0.426)$ & $0.78 * *(0.075)$ & $1.73 * *(0.021)$ & $1.27 \quad(0.451)$ \\
\hline \multicolumn{6}{|l|}{ Industry } \\
\hline - Manufacturing & Ref. & Ref. & Ref. & Ref. & Ref. \\
\hline - Construction & $0.63 \quad(0.254)$ & $0.52 *(0.303)$ & $0.51 \quad(0.422)$ & $0.82 \quad(0.161)$ & $0.27 * *(0.297)$ \\
\hline - Services & $0.44 * *(0.282)$ & $0.46^{* *}(0.073)$ & $0.94 \quad(0.428)$ & $0.97 \quad(0.079)$ & $1.07 \quad(0.159)$ \\
\hline - Public admin. and defence & $0.60 \quad(0.394)$ & $0.59 * *(0.089)$ & $0.92 \quad(0.276)$ & $0.83 \quad(0.187)$ & $0.72 \quad(0.276)$ \\
\hline - Others & $0.85 \quad(0.336)$ & $0.59 * *(0.172)$ & $1.19 \quad(0.175)$ & $2.72 * *(0.333)$ & $1.09 \quad(0.210)$ \\
\hline Public sector & $2.17 *(0.353)$ & $1.69 * *(0.120)$ & $2.54 * *(0.105)$ & $4.27 * *(0.084)$ & $2.31 * *(0.215)$ \\
\hline Union's influence at workplace & $1.63 * *(0.148)$ & $1.78 * *(0.019)$ & $1.95^{* *}(0.022)$ & $2.70 * *(0.040)$ & $2.27 * *(0.091)$ \\
\hline \multicolumn{6}{|l|}{ Establishment size } \\
\hline - Under 10 & Ref. & Ref. & Ref. & Ref. & Ref. \\
\hline-10 to 24 & $1.25^{* *}(0.056)$ & $1.25 \quad(0.190)$ & $1.34 * *(0.076)$ & $1.26 \quad(0.131)$ & $1.30 \quad(0.202)$ \\
\hline-25 to 99 & $1.52 *(0.186)$ & $1.28 \quad(0.168)$ & $1.17 \quad(0.354)$ & $1.59 * *(0.107)$ & $2.05^{* * *}(0.183)$ \\
\hline - 100 to 499 & $1.85^{* *}(0.094)$ & $1.49^{*}(0.185)$ & $0.91 \quad(0.174)$ & $1.70 * *(0.156)$ & $3.24 * *(0.150)$ \\
\hline - 500 or more & $1.50 *(0.161)$ & $1.90 *(0.254)$ & $0.87 \quad(0.246)$ & $1.49 * *(0.144)$ & $4.69 * *(0.217)$ \\
\hline \multicolumn{6}{|l|}{ Country-level control } \\
\hline Ghent system & $3.68 * *(0.115)$ & $7.75^{* *}(0.095)$ & N/A & N/A & N/A \\
\hline Number of observations & 2,849 & 3,748 & 2,483 & 1,803 & 4,290 \\
\hline $\mathrm{BIC}$ & $2,857.7$ & 3524.5 & $1,890.1$ & $1,705.5$ & $2,672.8$ \\
\hline
\end{tabular}

Note: Odds ratios and standard errors (in brackets).

$* p<0.05 ; * * p<0.01 ;$ Ref. $=$ reference category 


\section{Discussion and conclusions}

Table 6 summarizes our results. Comparing the top and bottom halves of the table shows that there are, indeed, interesting differences between the unionisation rates of the family policy related NSR groups (single-parent employees, female employees with children and female caregivers) and precarious workers (low-skilled service employees, temporary employees and part-timers). The argument often presented in the earlier literature that NSR groups are less unionised than average workers (Bonoli, 2005; Ebbinghaus, 2006; Häuserman, 2012) only holds for precarious workers, and even among them only in certain IR regimes. Family policy related NSR groups are, in fact more unionised, not less, than the average worker, even though this result, too, only holds in some IR regimes.

Table 5 Associations between NSR groups and union membership

\begin{tabular}{cccccc}
\hline NSR group & $\begin{array}{c}\text { Organised } \\
\text { corporatism }\end{array}$ & $\begin{array}{c}\text { Social } \\
\text { partnership }\end{array}$ & $\begin{array}{c}\text { Polarised/ } \\
\text { state-centred }\end{array}$ & Liberal & Transitional \\
\hline Single-parent employees & $N S$ & $N S$ & $N S$ & + & $N S$ \\
$\begin{array}{c}\text { Female employees } \\
\text { with children }\end{array}$ & + & + & $N S$ & + & $N S$ \\
$\begin{array}{c}\text { Female employees who care for } \\
\text { vulnerable family members } \\
\text { Low-skilled }\end{array}$ & $N S$ & $N S$ & $N S$ & + & $N S$ \\
$\begin{array}{c}\text { service employees } \\
\text { Temporary employees }\end{array}$ & $N S$ & $N S$ & $N S$ & + & - \\
Part-time employees & $N S$ & - & $N S$ & - & - \\
\hline
\end{tabular}

Note: + = more likely to have union membership; - = more unlikely to have union membership; $N S=$ not significant 
Thus, our findings confirm that the efforts of trade unions to mobilise the family policy related NSR groups that have been identified in earlier literature (Eurofound, 2010) have been successful. Apart from the unions' work, two wider trends may have contributed to this success. First, during the past couple of decades, the European Union has emphasised welfare reform focussing on work-life balance. Family policies, in particular parental leave, have been one of the key social policy issues in Europe, and trade unions have been favourable to and active in extending such policies in many European countries (Budd and Mumford, 2004; Haas, 2003; Kittilson, 2008). Second, the number of working mothers in Europe has increased for several decades, and currently about one out of five employees is a working mother across the IR regimes (see Table 1).

In fact, this trend has continued so long and the share has grown so high that one might even want to question the idea of naming working mothers "a new social risk group", or consider them atypical workers in any way. To better engage with existing research, in this paper we retained Bonoli's (2005) original definition and included working mothers as a separate group. This resulted in the interesting finding that this particular NSR group is more unionised - not less - than the average worker in three out of five IR regimes. We may thus conclude that working mothers have grown into a large 
group that has taken its place and asserted its needs in the system of collective bargaining across Europe.

We also found significant effects of the macro-level context on the unionisation rates of NSR groups. As we hypothesized, precarious workers tend to be less unionised in the liberal and transitional regimes, where collective bargaining coverage is low. This is in line with arguments of the existing literature on NSRs and union membership: because of the different organisation of workplaces and the unwillingness and inability of unions to protect precarious workers, they have been less likely to unionise.

Our findings, however, make three important qualifications to this general claim presented in the literature. First, as we hypothesized based on the literature discussing IR regimes and unionisation, in the three regimes where collective bargaining coverage is high (organised corporatism, social partnership and state-centred), the wide coverage tends to mitigate the negative effects of precariousness on unionization.

Second, we found against our hypothesis that temporary employees in the social partnership regime and part-timers in the polarised/state-centred regime are less unionised than average. The organised corporatism regime is the only one where no precarious worker group is less unionised than other workers. This suggests that the mitigating effect of the high collective bargaining coverage is only partial, and that there is something particular about the organised corporatism regime that helps unionisation of precarious workers. A possible explanation is that in the organised corporatism the 
power balance between workers and employers is inclined to labour and employees are represented mostly by industry based trade unions, whereas labour is less powerful and employee representation tends to be divided into various organisations such as works councils, workplace-level and industry-level unions in the other IR regimes (European Commission, 2009) Those features of the organised corporatism regime are more likely to attract people in precarious job position to unions.

Third, and counter to our hypothesis again, we found that even in the liberal regime, low-skilled service employees are more unionised than the average worker, at the same time as temporary employees and part-timers are less unionised, as expected. What could explain the counterintuitive status of the low-skilled service workers? Eurofound's (2010) report provides evidence to explain the phenomenon. The report describes that trade unions in Cyprus, Ireland, and the UK in common targeted private service sectors such as wholesale and retail trade and cleaning and catering services for the purpose of recruiting new members in the 2000s, and they have been successful in increasing union density in the target sectors.

This leads us to conclude that conscious mobilisation efforts by unions can make a big difference. By rebuilding their strategies reacting to the transformation of labour markets, unions can succeed. And this can happen even where the macro-contextual factors are against them, that is, in the liberal IR regime where collective bargaining coverage is low. This is all the more remarkable considering that they have been 
successful in the case of low-skilled service workers, because in their case meso-level conditions at the workplace are often against unionisation as well. Compared to the traditional factory setting where face-to-face contact with a large number of co-workers is often fairly regular, or skilled office work where hours tend to be fairly regular, team work increasingly frequent and employee turnover relatively low, low-skilled service workplaces where workmates are fewer, hours more irregular and turnover high, constitute a challenge for unionization efforts. The fact that unions have succeeded in countering the unfavourable meso and macro contexts in the case of precarious workers in the liberal IR regime suggests that the reports about the death of unions due to unfavourable structural trends in societies and workplaces (Liu, 2013; Steingart, 2006) may be, at least to some degree, exaggerated.

Overall, our results indicate that unions may be better able to respond to the rise of new social risks than the literature has tended to argue. We have shown that the family policy related NSR groups are, if anything, more unionised than others, suggesting that efforts by unions and policymakers across Europe to respond to the needs of these groups have paid off. While precarious workers, on the other hand, do tend to be less unionised than others, even among these groups, where unions have worked hard they have succeeded - even in countries of the liberal IR regime where post-industrialisation has proceeded the most rapidly among European countries. While these successes fall short of reversing the trend of overall degree of unionisation, they 
may indicate that unions are, at least to some degree, able to shift their focus from old social risks to new ones as the growth of the latter proceeds. This does, however, require that unions understand the divergent needs of different NSR groups and use this understanding to create a diversity of personal services in addition to cash benefits for workers.

\section{References}

Allern, E.H., Aylott N. and Christiansen F.J. (2007) 'Social Democrats and trade unions in Scandinavia: The decline and persistence of institutional relationships', European Journal of Political Research 46(5): 607-635.

Blanchflower, D.G. (2007) 'International patterns of union membership', British Journal of Industrial Relations 45(1): 1-28

Bonoli, G. (2005). 'The politics of the new social policies: providing coverage against new social risks in mature welfare states', Policy \& politics 33(3), 431-449.

Bonoli, G. (2006) 'New social risks and the politics of post-industrial social policies', in $\mathrm{K}$. Armingeon and G. Bonoli (eds) The politics of post-industrial welfare states: Adapting post-war social policies to new social risks, pp. 3-26. Abingdon: Routledge.

Bonoli, G. (2007) 'Time Matters: Postindustrialization, New Social Risks, and Welfare State Adaptation in Advanced Industrial Democracies', Comparative Political Studies 40(5): 495-520.

Brady, D. (2007) 'Institutional, economic, or solidaristic? Assessing explanations for unionization across affluent democracies', Work and Occupations 34(1): 67101.

Budd, J.W. and Mumford, K. (2004) 'Trade unions and family-friendly policies in Britain', Industrial \& Labor Relations Review 57(2): 204-222.

Crouch, C. (1993) Industrial relations and European state traditions. Oxford: Oxford University Press. 
Earles, K. (2011) 'Swedish Family Policy - Continuity and Change in the Nordic Welfare State Model', Social Policy \& Administration 45(2): 180-193.

Ebbinghaus, B. (2006) 'Trade union movements in post-industrial welfare states: Opening up to new social interests?', in K. Armingeon and G. Bonoli (eds) The politics of post-industrial welfare states: Adapting post-war social policies to new social risks, pp. 123-142. Abingdon: Routledge.

Ebbinghaus, B. and Visser, J. (1997) 'Der Wandel der Arbeitsbeziehungen im westearopaischen Vergleich', in S. Hradil and S. Immerfall (eds) Die westearopäischen Gesellschaften im Vergleich. Leske + Budrich, Opladen.

Ebbinghaus, B., Göbel C. and Koos S. (2011) 'Social capital, 'Ghent'and workplace contexts matter: Comparing union membership in Europe', European Journal of Industrial Relation, 17(2): 107-124.

Esping-Andersen, G. (1999) Social Foundations of Postindustrial Economies. Oxford: Oxford University Press.

Eurofound (2010) Trade union strategies to recruit new groups of workers - each country's contribution. Available at: www.eurofound.europa.eu/observatories/eurwork/comparative-information (accessed 19 Apr 2016).

European Commission (2009) Industrial Relations in Europe 2008. Luxembourg: Office for Official Publications of the European Communities.

European Commission (2014) Eurostat. Available at: http://epp.eurostat.ec.europa.eu/portal/page/portal/eurostat/home/ (accessed 8 Sep 2014).

European Social Survey (2014) Weighting European Social Survey Data. Available at: www.europeansocialsurvey.org/

European Trade Union Institute (2014) National Industrial Relations. Available at: www.worker-participation.eu/National-Industrial-Relations (accessed 15 Apr 2016).

Gallie, D. (2007) 'Production regimes, employment regimes, and the quality of work', in D. Gallie (ed) Employment Regimes and the Quality of Work. Oxford: Oxford University Press.

Gregory, A. and Milner, S. (2009) 'Trade Unions and Work- life Balance: Changing Times in France and the UK?', British Journal of Industrial Relations 47(1): 122-146. 
Gumbrell-McCormick, R. (2011) 'European trade unions and atypical workers', Industrial Relations Journal 42(3): 239-310.

Haas, L. (2003) 'Parental leave and gender equality: Lessons from the European Union', Review of Policy Research 20(1): 89-114.

Harsløf, I. and Ulmestig, R. (2013) 'Introduction: Changing Social Risks and Social Policy Responses in the Nordic Welfare States, in I. Harsløf and R. Ulmestig (eds) Changing Social Risks and Social Policy Responses in the Nordic Welfare States, pp. 1-24. London: Palgrave Macmillan.

Häusermann, S. (2012). 'The politics of old and new social policies', in G. Bonoli and D. Natali (eds) The politics of the new welfare state, pp. 111-134. Oxford: Oxford University Press.

Häusermann, S. and Schwander, H. (2012) 'Varieties of dualization? Labor market segmentation and insider-outsider divides across regimes', in P. Emmenegger, S. Häusermann, B. Palier and M. Seeleib-Kaiser (eds) The Age of Dualization: The changing face of inequality in deindustrializing societies, pp. 27-51. Oxford: Oxford University Press.

Hox, J.J. and Roberts J.K. (2011) 'Multilevel analysis - where we were and where we are', in J.J. Hox and J.K. Roberts (eds) Handbook of advanced multilevel analysis, pp. 3-11. New York: Routledge.

Kalleberg, A.L. (2009) 'Precarious work, insecure workers: Employment relations in transition', American sociological review 74(1): 1-22.

Kemppainen, T. (2012) Well-being in socio-political context. European welfare regimes in comparison. Studies in social security and health 123 . Helsinki: The Social Insurance Institution of Finland.

Kittilson, M.C. (2008) 'Representing women: The adoption of family leave in comparative perspective', The Journal of Politics 70(02): 323-334.

Liu, E. (2013) 'Viewpoint: The Decline of Unions Is Your Problem Too', Time Magazine Online. Available at: http://ideas.time.com/2013/01/29/viewpointwhy-the-decline-of-unions-is-your-problem-too/. (accessed 11 Nov, 2016).

Morel, N., Palier, B. and Palme, J. (2012) Towards a social investment welfare state? Ideas, Policies and Challenges. Bristol: Policy Press.

Rothstein, B. (1990) 'Marxism, institutional analysis, and working-class power: the Swedish case', Politics \& Society 18(3): 317-345.

Scheuer, S (2011) 'Union membership variation in Europe: A ten-country comparative analysis', European Journal of Industrial Relations 17(1): 57-73 
Schnabel, C. and Wagner, J. (2007) 'Union density and determinants of union membership in 18 EU countries: evidence from micro data, 2002/03', Industrial Relations Journal 38(1): 5-32.

Schneider, S.L. (2009) Confusing Credentials: The Cross-nationally Comparable Measurement of Educational Attainment. PhD Thesis, University of Oxford, UK.

Steingart, G. (2006) 'A Casualty of Globalization: Death of the Unions', Der Spiegel Online. Available at: http://www.spiegel.de/international/a-casualty-ofglobalization-death-of-the-unions-a-445043.html (accessed 11 Nov 2016).

Taylor-Gooby, P. (2004) 'New social risks in postindustrial society: some evidence on responses to active labour market policies from Eurobarometer', International Social Security Review 57(3): 45-64.

Vandaele, K. (2006) 'A report from the homeland of the Ghent system: unemployment and union membership in Belgium', Transfer 13(4): 647-657.

Weiler, A. (2004) Quality in industrial relations: Comparative indicators. European Foundation for the Improvement of Living and Working Conditions. Luxembourg: Office for Official Publications of the European Communities.

Western, B. (1994) 'Institutional mechanisms for unionisation in sixteen OECD countries: an analysis of social survey data', Social Forces 73(2): 497-519.

Yerkes, M. and Tijdens, K. (2010) 'Social risk protection in collective agreements: Evidence from the Netherlands', European Journal of Industrial Relations 16(4): 369-383. 